TITLE:

\title{
Proposing a common platform of shipping cost analysis of the Northern Sea Route and the Suez Canal Route
}

\section{AUTHOR(S):}

Furuichi, Masahiko; Otsuka, Natsuhiko

\section{CITATION:}

Furuichi, Masahiko ... [et al]. Proposing a common platform of shipping cost analysis of the Northern Sea Route and the Suez Canal Route. Maritime Economics \& Logistics 2014, 17(1): 9-31

ISSUE DATE:

2014-10-09

URL:

http://hdl.handle.net/2433/198733

\section{RIGHT:}

This is a post-peer-review, pre-copyedit version of an article published in [Maritime Economics \& Logistics]. The definitive publisher-authenticated version [Masahiko Furuichi, Natsuhiko Otsuka. Proposing a common platform of shipping cost analysis of the Northern Sea Route and the Suez Canal Route. 17, 9-31] is available online at: http://dx.doi.org/10.1057/mel.2014.29.; 許諾条件により本文ファイルは2016-04-09に公開.; この論文は出版社版であり ません。引用の際には出版社版をご確認ご利用ください。; This is not the published version. Please cite only the published version. 


\title{
Proposing a common platform of shipping cost analysis of the Northern Sea Route and the Suez Canal Route
}

\author{
Masahiko Furuichi \\ Graduate School of Management, Kyoto University \\ Yoshida-Honmachi, Sakyo-ku, Kyoto, 606-8501, Japan \\ Telephone: +81-75-753-5104 \\ e-mail: furuichi.masahiko@gsm.kyoto-u.ac.jp \\ Natsuhiko Otsuka \\ North Japan Port Consultants, Ltd. (NJPC) \\ South-2, East-2, 8-1, Chuo-ku, Sapporo, 060-0052, Japan \\ Telephone: +81-11-251-8601 \\ e-mail: otsuka@njpc.co.jp
}

\begin{abstract}
Maritime trade between East Asia and Northwest Europe using the Northern Sea Route (NSR) has been increasing, because of the shorter sailing distance of NSR, of which navigable season has been extending due to the global warming. In 2013, the NSR shipping marked a record ten year-high volume of 1.36 million tons with 71 voyages. Accordingly, comparative analyses of shipping cost via the NSR and the alternative conventional routes, especially the Suez Canal Route (SCR), have been carried out. Furthermore, NSR/SCR-combined shipping, when a vessel transits the NSR during summer and the SCR in winter, has already been proposed as a realistic scenario.

Since assumptions used in the cost estimations vary among the studies, there remain some difficulties when comparing the estimated shipping costs. This study aims at establishing a common platform of a wide range of cost estimation assumptions through clarifying and analysing cost components contained in the current literature. In addition, interviews with NSR shipping professionals were conducted concerning the NSR fee on an unofficial basis, because these fees are determined based on negotiations between ice breaker escort service provider and shipping company. An empirical analysis revealed that NSR/SCR-combined shipping of container cargo between East Asia and Northwest Europe can be commercially feasible.
\end{abstract}

Keywords: Shipping Cost Analysis, Maritime Transport, Northern Sea Route (NSR), Suez Canal Route (SCR) 


\section{Introduction}

Maritime container cargo currently transported via the SCR between East Asia and Northwest Europe could potentially divert to the NSR. Shippers of vehicles, in particular, which are also the most valuable cargo to be transported directly from one point to the other between East Asia and Northwest Europe, would like to take advantage of the significant reduction in sailing distance via the NSR. Natural resources produced in the Arctic region, are also potential cargoes. Gas condensate from Murmansk (Russia), LNG from Hammerfest (Norway) and iron ore from Kirkenes (Norway), have already been commercially shipped to East Asia via the NSR since 2010. In 2012, the NSR sailing season started in late June with the last voyage completed in late November. This period represented the longest NSR navigation season ever. This paper aims at establishing a common platform of shipping cost assumptions to achieve comparative cost analysis of NSR and SCR shipping. Seasonal limitations of NSR shipping for various scenarios are also discussed.

Arctic navigation requires specifically designed and equipped ships i.e. ice-class ships as well as ice breaker escort along the NSR. Economic feasibility of the ice-class ship operations for NSR shipping should be analysed on a yearly operation basis. NSR/SCR-combined shipping is proposed as a combined shipping scenario in which the NSR is used in the summer time and the SCR for the rest of the year (hereinafter referred to as "NSR/SCR-combined shipping”), taking the NSR service period of the year into account. A wide variety of scenarios are prepared and analysed. Detailed components of shipping costs: i) capital cost (depreciation cost), ii) NSR fee, iii) ice pilot fee, iv) Suez Canal fee, v) crew cost, vi) maintenance cost, vii) insurance cost, viii) fuel cost, and ix) port dues (including container handling charges) are individually analysed based on certain assumptions found in the related literature. The shipping cost analysis revealed that fuel cost dominates the conventional SCR shipping, while the fuel cost is less important in NSR shipping, given the shorter sailing distance as well as the slower operational sailing speed in the ice waters. In conclusion, NSR/SCR-combined shipping of container cargo between East Asia and Northwest Europe can be commercially feasible when a level of cost components are realistically assumed.

\section{Literature review}

Isakov et al. (1999) was the first pioneering study on the economic feasibility of shipping natural resources produced in the Arctic region, i.e. crude oil, LNG and timbers via the NSR. 'The Northern Sea Route' by the Ship and Ocean Foundation (2000) is the seminal full-scale study on technical and economic feasibility of the NSR commercial shipping between Yokohama and Hamburg. That study assumed the operation of an ice-breaking bulk/container ships of 40,000 DWT and 50,000DWT. The study proposed NSR/SCR-combined shipping by the ice-breaking bulk/container ship on a yearly operation basis, compared to SCR shipping by the ordinary bulk/container ship. The unit cost of NSR/SCR-combined shipping of general 
cargo was estimated at 18 (USD/ton), which is approximately equal to that of SCR shipping when an ordinary ship of the same size is deployed and ice breaker escort service is provided at discounted rate by $26 \%$. Consequently, no significant comparative advantage of NSR/SCRcombined shipping was identified.

Arpiainen and Killi, (2006) made a systematic cost analysis of container transport between Alaska and Iceland, by assuming double-acting container ships of 750 TEU and 5,000 TEU, which can sail either forward as a normal ship in ordinary waters or astern-ward as an ice breaker in ice waters. Since this ice-breaking container ship is able to navigate the NSR without escort by the Russian ice breakers, NSR fee was not applied to the cost analysis although the Russian regulation requires an ice breaker escort for all vessels sailing via the NSR. Shipping unit costs of containers were estimated at 345-526 (USD/TEU) for the 5,000 TEU ship and 1,244-1,887 (USD/TEU) for the 750 TEU ship, which were equivalent to the container shipping tariffs between Japan and Europe. In this context, NSR commercial shipping would also be presumably evaluated as feasible, although there was no cost analysis on the route linking East Asia and Europe.

Verny and Grigentin (2009) made a cost analysis of container transport between Shanghai and Hamburg based on the development of a 4,000 TEU ice-class ship operating on different routes: the SCR, Siberia Land Bridge (SLB) route and Sea \& Air route. Shipping unit costs of container were estimated at 2,500-2,800 (USD/TEU) for NSR shipping, twice as much as those of SCR shipping (1,400-1,800 (USD/TEU)). Consequently, NSR shipping was not considered feasible since the building cost of a new 4,000 TEU ice-class ship was assumed at USD 180 million which is four times as much as the average building cost (USD 47 million) of a new 4,000 TEU ordinary ship in 2012.

Liu and Kronbak, (2010) made a comprehensive analysis of container shipping cost between Yokohama and Rotterdam by assuming a 4,300 TEU ice-class ship would be introduced. This analysis was based on NSR/SCR-combined shipping on a yearly operation basis. Total cost of NSR shipping is most influenced by the following three factors; i) NSR service period in a year, ii) NSR fee, and iii) fuel cost. Accordingly several scenarios were set in which the values of those factors varied. For the NSR service period, 90 days, 180 days and 270 days were applied while 50\%-off, 80\%-off and 100\%-off were applied for NSR fees, and 350 (USD/ton), 700 (USD/ton) and 900 (USD/ton) for fuel cost. NSR/SCR-combined shipping was evaluated infeasible for most of the scenarios because the NSR fee of 979 USD/TEU assumed in the analysis is extremely high. However, NSR/SCR-combined shipping could be feasible if NSR fee were free (100\%-off) and the fuel cost ranged between 700 and 900 (USD/ton).

Schoyen and Brathen, (2011) examined economic feasibility of bulk cargo (tramp) shipping of nitrogen fertilizer and iron ore produced in the Arctic region to be exported to East Asia, taking the uncertain schedule reliability of NSR shipping into account. Shipping unit cost of 
nitrogen fertilizer was estimated at 42.6 (USD/ton) for NSR shipping compared to 43.3 (USD/ton) for SCR shipping. Similarly, shipping unit cost of iron ore was estimated at 37 (USD/ton) for NSR shipping, compared to 39 (USD/ton) for SCR shipping. Furthermore, NSR shipping is twice as energy efficient as SCR shipping in view of fuel consumption, taking the slow operational sailing speed in the ice waters into account. Estimated shipping unit costs of raw materials are nearly the same between NSR and SCR shipping.

Omre (2012) examined the technical and economic feasibility of container shipping between Yokohama and Rotterdam, by assuming ice-class container ship of 3,800 TEU. This analysis was based on NSR/SCR-combined shipping on a yearly operation basis. Sensitivity analysis involving several scenarios of the NSR service period and different fuel costs was undertaken to establish shipping unit costs. The NSR service periods were set at 70 days, 100 days and 120 days, and similarly the fuel costs were set at 400 (USD/ton), 550 (USD/ton) and 700 (USD/ton). A remarkable feature of the study is that the cost estimation was made by assuming that fuel consumption per distance unit is proportional to the square of sailing speed. The NSR fee was also set at a reasonable level of 5.0 (USD/GT) in the analysis, which is nearly the same value obtained by the authors when interviewing NSR shipping professionals. Consequently, NSR/SCR-combined shipping was evaluated to be feasible in all scenarios.

In conclusion, in recent years NSR shipping (including NSR/SCR-combined shipping) has been evaluated as feasible under various scenarios. In contrast, earlier studies concluded that NSR shipping was not economically viable. The more recent feasible evaluations are based on an extended NSR operating season and a fuel price appreciation in recent years. Both of these factors are critical in assessing the NSR as a viable alternative to other routings between East Asia and Northwest Europe.

\section{Cost components of maritime shipping}

Maritime shipping cost components can be seen from an operator's viewpoint or a shipowner's viewpoint (Ship and Ocean Foundation, 2000, and Hino, 2011). Typical examples of the differing viewpoints are presented in Table 1.

\section{Insert Table 1}

\subsection{Capital cost and depreciation cost}

Both capital cost and depreciation cost are applied to a yearly repayment and a yearly depreciation of the capital based on the building cost of a new ship. In the study by the Ship and Ocean Foundation (2000), the concept of the capital cost was introduced as a yearly repayment (i.e. equivalent to a repayment of $10.9 \%$ of the capital cost for 15 years) of the new ship as defined by certain conditions (an interest rate of $7 \%$ and a return period of 15 years), from the project finance viewpoint. 
On the other hand, in Hino (2011), depreciation cost was introduced as a yearly depreciation of the capital for the economic lifetime of 15 years in Japan, which is equivalent to a repayment of $6.7 \%$ of the capital cost for 15 years when applying straight-line method. Appropriate lifetime should be carefully assumed for the analysis, because economic lifetime varies according to the tax system of each country, e.g. 8 years in France, 10 years in Germany and 15 years in Japan.

Building costs of ordinary new ships were estimated for various ship-types and sizes referring to the actual transactions (see Table 2).

\section{Insert Table 2}

In addition, related studies (Liu and Kronbak, 2010, and Omre, 2012) pointed out that special attention should be drawn to the fact that the cost of a new ice-class ship is $10-30 \%$ higher than an ordinary ship of the same size.

\subsection{NSR fee}

NSR fee is required by the Russian state-owned enterprise which runs nuclear-powered ice breakers. The fee varies in accordance with the ice class of each vessel, ice condition, sea area and navigation season, as determined based on negotiations between the state-owned enterprise and clients. Here, the NSR fee should not exceed an upper limit of official NSR tariff, which has been updated by the Russian Government in 2014 (Russian Ministry of Justice, 2014). As reported by an operator engaged in NSR commercial shipping in recent years, the actual NSR fee was 5.0 (USD/GT) (Falck, 2012). Therefore, Omre (2012) adapted NSR fee of 5.0 (USD/GT) in his study.

\subsection{Ice pilot fee}

The ship master (captain) on a bridge watch must possess the minimum level of knowledge of navigation in the ice-covered waters and have experience in piloting ships under ice conditions along the NSR for not less than 15 days. In the absence of such experience, the presence of an ice pilot aboard the ship is compulsory. Ice pilot fee was stipulated as 673 (USD/day) for the NSR navigation between Kara and Bering straits in the former Russian law. This tariff rate was abolished in 2013, and since then the ice pilot fee has been determined based on negotiations between piloting company and clients (Russian Federal Law, 2012).

\subsection{Suez Canal fee and Panama Canal fee}

Suez Canal fee is determined for each ship type based on Suez Canal Net Tonnage (SCNT) which can be approximated by gross tonnage (GT) of the ship (Suez Canal Authority Website, 2012). Table 3 presents the Suez Canal fee as of December 2012. However, it should be noted that a wide variety of discounts are available for specific ship types. 


\section{Insert Table 3}

Panama Canal fee is similarly determined for each ship type in SDR (Special Drawing Right) unit based on Panama Canal Universal Measurement System (PC UMS) which can be also approximated by gross tonnage (GT) of the ship (Panama Canal Authority Website, 2012). Table 4 presents the Panama Canal fees as of December 2012.

\section{Insert Table 4}

\subsection{Crew cost}

Crew sizes of a container ship, PCC or dry bulk ship, are practically 23-25 per ship, regardless of ship-size. Japan Ship-owners Association (2012) revealed that an average annual crew cost is estimated at approximately 1.0 million (USD/ship/year). On the other hand, crew size of LNG ship is approximately 45 per ship which is almost twice as large as for the abovementioned ships. Consequently, the average annual crew cost is similarly estimated at 2.0 million (USD/ship/year) for LNG ship.

\subsection{Maintenance cost}

Maintenance cost is comprised of article cost of ship, lubricant cost, dock cost and spare parts cost. Hino, (2011) estimated the annual maintenance cost of a dry bulk ship of 55,000 DWT as 383 thousand (USD/year) with the ship building cost of 35 million (USD/ship). With these values the annual maintenance cost can be determined proportional (1.095\% /year) to the ship building cost for any ship type.

\subsection{Insurance cost}

An ocean-going ship is generally required to purchase both $H \& M$ and $P \& I$ insurance. However, estimating insurance cost is a difficult task because insurance market transactions are not usually disclosed to the public due to the nature of the insurance business. Hino, (2011) estimated the annual insurance premium of both H\&M and P\&I insurance as 120 thousand (USD/year) in total for a dry bulk ship of 55,000 DWT, of which ship building cost is 35 million (USD/ship). Accordingly, annual insurance premium of both H\&M and P\&I insurance in total can be determined proportional (0.343\%/year) to the ship building cost for any ship type.

On the other hand, Ship and Ocean Foundation (2000) suggested that annual insurance premium of 10 (USD/GT/year) in total for both H\&M and P\&I additional insurance is compulsory for NSR shipping. NSR shipping may need to bear a certain disadvantage of the insurance premium due to the uncertainties and risks involved in sailing in the ice waters. 
Apart from the ordinary insurance cost, Aden Emergency Charge (40USD/TEU) is applied to the shippers of container cargo via the SCR as a kind of insurance premium for piracy off Somalia (MOL, 2012). The risk of piracy is a significant disadvantage to SCR shipping.

\subsection{Fuel cost}

Fuel cost accounts for a significant portion of the shipping cost, reflecting the fact that fuel prices have been increasing at a consistent pace for the last twenty years (Figure 1). The relationship that fuel consumption per distance unit is proportional to the square of sailing speed is recommended to apply for calculation.

\section{Insert Figure 1}

\subsection{Port dues}

Port dues usually consist of port entry charge, berthing charge and line-handling charge. Assuming 0.092 (USD/GT/call) for port entry due and berthing due respectively, and 0.244 (USD/GT/call) for line-handling charge, total port due was estimated at 0.428 (USD/GT/call) for each port entry by Ship and Ocean Foundation (2000) based on its analysis of costs in the ports of Yokohama, Hamburg, Dikson and Tiksi.

Port entry charges of bulk cargo ships are only paid twice: at the port of loading and the port of unloading, regardless of whether the NSR or the SCR is used. On the other hand, typical container ship operation via the SCR between East Asia and Northwest Europe may require 10 port calls, visiting major in-between ports as well as both end ports so as to accommodate abundant demand. Therefore, 10 port calls are assumed for a single voyage of a SCR container ship in this study.

Container handling charge of 100 (USD/TEU) is assumed to be added to the port dues for loading and discharging respectively at both end ports of a specific origin and destination pair, so as to easily compare the estimated shipping unit cost with the container shipping tariff of the same origin and destination pair on CIF basis.

\section{Practical NSR/SCR-combined shipping scenarios}

Container transport between Asia and Europe has significantly increased in the last 15 years and reached approximately 21 million TEUs in 2011, which could be potential demand for NSR shipping (see Figure 2). When setting the practical scenarios for NSR shipping as well as the alternative route shipping, researchers need to take various factors into account, e.g. the NSR service period, maximum ship-size on the NSR, ship building cost of the ice-class, nominal sailing speed in the ordinary waters, and operational sailing speed in the ice waters and the ordinary waters. Furthermore, special attention should be paid to the cargo demand 
distribution along the NSR, the SCR and other alternative routes, when assuming the shipping scenarios of container transport.

When focusing on container transport, NSR shipping may take full advantage of shorter transport time due to reduced sailing distance and avoiding major risks of SCR shipping, i.e. piracy risk off Somalia and choke-points such as the Malacca Strait. Container ship operators need to understand that there is almost no population and container demand along the NSR, while they are able to consolidate abundant cargo demand to and from Asian major hub ports along the SCR.

\subsection{NSR service period and sailing speed}

Many previous studies have been undertaken on container shipping via the NSR to examine the significant advantage of reduced sailing distance compared to SCR shipping between East Asia and Northwest Europe. However, since container shipping may require a fixed scheduled operation, disadvantage of NSR's limited service period, which is only 4 to 6 months of the year, is equally significant.

When setting the scenarios for NSR shipping, the range of the NSR service period is assumed to be 3.5 months (105 days) to 7.5 months (225 days) taking the recent records of NSR commercial shipping into account. Since the operational sailing speed in the ice waters is relatively slow compared to that in the ordinary waters, the operational sailing speed is recommended to be set at 12 to 15 knots.

\subsection{Maximum ship-size for NSR shipping}

The ordinary NSR has a draft restriction of $11.0 \mathrm{~m}$ at the Sannikov Strait, and breadth restriction of 33-49 $\mathrm{m}$, which is determined by the breadth of ice breaker(s). Since the NSR passage to the north of New Siberian Islands was made available due to the sea ice retreat in 2011, larger ships have been able to transit the NSR since then. Principal characteristics should be appropriately determined for container ship.

\subsection{Ice-class ship building cost}

Ships sailing through the NSR are recommended to satisfy PC7 (e.g. RS Arc4, NK IA) or better, which may entail an additional 10-30\% building cost (Liu and Kronbak, 2010, and Omre, 2012). When setting the scenarios, the percentage (10\%) of the additional ship building cost should be assumed, taking additional ship weight into account.

\subsection{Operational sailing speed and fuel consumption}

Fuel consumption of the sailing ship is computed by multiplying SFOC (Specific Fuel Oil Consumption) (g/kWh), engine power (kW) and sailing hours (h). Since ice-class ships consume more fuel than the ordinary ships, mainly due to the additional weight of reinforced 
thick steel hull, premium (10\%) for SFOC of ice-class ship should be assumed proportionally to the additional ship weight of $10 \%$.

SFOC is fixed at a level of 185 ( $\mathrm{g} / \mathrm{kWh}$ ), regardless of ship type, which may decrease proportionally to the square of operational sailing speed. Therefore, fuel consumption reduction effect increases when the operational sailing speed is slower than the nominal sailing speed (Omre, 2012).

\subsection{NSR/SCR-combined shipping scenarios for container transport}

When setting the scenarios for container transport between e.g. Yokohama and Hamburg via the NSR, 4,000 TEU ice-class container ships are assumed to be used since they can generate economy of scale effect. On the other hand, medium, large and ultra-large container ships of the 4,000 TEU, 6,000 TEU, 8,000 TEU and 15,000 TEU-classes are to be selected for the alternative route shipping via the SCR.

Load factor of the container ship should be assumed as $70 \%$ for eastward and westward sailing respectively, taking liner shipping characteristics into account.

\subsection{Various aspects of NSR/SCR-combined shipping evaluation}

Maritime shipping industry is a capital-intensive industry which by nature aims at maximizing profit on a yearly operation basis. It's possible that NSR shipping could achieve more voyages than SCR shipping between e.g. East Asia and Northwest Europe by taking advantage of reduced sailing distance. Consequently, the more annual shipment from one place to the other on a yearly operation basis is expected for NSR/SCR-combined shipping, so that the maritime shipping industry is able to generate more profits than the simple SCR shipping operation. Thus, the annual shipment capacity of NSR/SCR-combined shipping may become a useful measure from the financial viewpoint.

Secondly, speedy transport of valuable cargo via the NSR due to reduced sailing distance compared to SCR shipping may bring a significant competitive advantage. Reduced transport time is of greater importance to the high-value cargo shippers and consignees.

Thirdly, NSR shipping may reduce fuel consumption, because of reduced sailing distance and higher energy efficiency gained by reduced sailing speed in the ice waters. $\mathrm{CO}_{2}$ emission can be calculated, by assuming that carbon dioxide be produced 3.19 ton by burning 1.0 ton of bunker fuel (IMO, 2009). Emission reduction effect by unit cargo between the same origin and destination pair may become a beneficial index from the greener shipping viewpoint. 


\section{Empirical analysis of NSR/SCR combined shipping}

An empirical analysis is now undertaken for the container transport between East Asia (Yokohama) and Northwest Europe (Hamburg) assuming realistic values for the main factors: i) NSR service period, ii) NSR fee, and iii) fuel cost. NSR/SCR-combined shipping scenarios and level of nine (9) cost components are discussed in Chapter 4 for the empirical analysis are summarized in Tables 5 and 6 respectively. Cost estimation is based on a yearly operation basis, assuming NSR/SCR-combined shipping which combines NSR shipping for the summer time and SCR shipping for the rest of the year. This provides a common platform to compare NSR/SCR-combined shipping unit cost with SCR shipping unit cost on the same operational basis, which is important from the financial viewpoint.

\section{Insert Table 5}

\section{Insert Table 6}

\subsection{Shipping unit cost comparison per TEU}

\subsubsection{Cost component breakdown}

Shipping unit cost per TEU is calculated and their cost components are given by ship-size for NSR/SCR-combined shipping and SCR shipping, assuming the following base scenario: the NSR service period of 105 days, fuel cost of 650 (USD/ton) and NSR fee of 5.0 (USD/GT). Shipping unit cost is calculated at 1,211 (USD/TEU) for NSR/SCR-combined shipping by the 4,000 TEU ice-class ship, which is compared to 1,355 (USD/TEU) for SCR shipping using an ordinary container ship of the same size. This is the same conclusion as Orme (2012).

Shipping unit costs of 1,320 (USD/TEU) and 1,211 (USD/TEU) are obtained for SCR shipping by ordinary large container ships of 6,000 TEU and 8,000 TEU respectively, which suggests that SCR shipping is less competitive than NSR/SCR-combined shipping. However, calculated shipping unit cost of 944 (USD/TEU) for SCR shipping by an ordinary ultra-large container ship of 15,000 TEU is much more competitive than NSR/SCR-combined shipping (4,000 TEU) due to the economy of scale that the ultra-large container ship offers.

\section{Insert Figure 4}

When looking at detailed cost components, fuel cost accounts for approximately $50 \%$ of the total shipping unit costs for all ship-sizes. Following the fuel cost, port dues occupy approximately 20\%, and capital cost and the Suez Canal fee including Aden emergency charge occupy approximately $10 \%$ respectively (Table A.1).

\subsubsection{Effect of the NSR service period}

Also shown in Figure 4 (right-hand side) are the shipping cost estimates per TEU on the NSR/SCR combined shipping scenarios for extended NSR service periods. When the NSR 
service period reaches 225 days, NSR/SCR-combined shipping (984USD/TEU) appears nearly competitive against SCR shipping (944USD/TEU) even when an ordinary ultra-large container ship of $15,000 \mathrm{TEU}$ is deployed. This also implies that NSR/SCR-combined shipping of container transport by the 4,000TEU ice-class container ship can be regarded as economically feasible to a certain extent, even though SCR shipping deploys large (between 6,000TEU and 8,000TEU) and/or ultra-large container ships (15,000TEU).

\subsubsection{Effect of NSR fee}

Scenario in which NSR fee is assumed to be 5.0 (USD/GT), is compared to the scenario in which NSR fee is assumed to be 979 (USD/TEU) as reported by Liu and Kronbak (2010) by calculating their cost components shown in Table 7. For the base scenario (the NSR service period is 105 days), NSR/SCR-combined shipping unit cost is calculated at 2,183 (USD/TEU), a $80 \%$ increase over 1,211 (USD/TEU). Accordingly, such an extremely high NSR fee setting of 979 (USD/TEU) undoubtedly makes NSR commercial shipping infeasible as indicated by the previous studies.

This clearly suggests that the recent NSR fee transactions of 5.0 (USD/GT) for bulk cargo shipping can be understood as practically competitive against the Suez Canal fee (Falck, 2012).

\section{Insert Table 7}

\subsubsection{Effect of fuel Costs}

For the base scenario (the NSR service period is 105 days), NSR/SCR-combined shipping unit cost is calculated at 856 (USD/TEU), 1,211 (USD/TEU) and 1,464 (USD/TEU) respectively when assuming fuel cost of 300 (USD/ton), 650 (USD/ton) and 900 (USD/ton), which is competitive against SCR shipping by the medium-size container ship (4,000 TEU) and the large container ship (6,000 TEU-8,000 TEU) respectively. If the NSR service period gets longer, this tendency remains the same.

\section{Insert Table 8}

\subsection{Comparison of the annual container shipment capacity}

NSR/SCR-combined shipping enables 13 to 15 voyages per year depending on the NSR service period (105days-225days), while the number of annual voyages is 12 for SCR shipping, achieving annual container shipment of 33,600 (TEU/year) by the ordinary 4,000 TEU ship. As the number of annual voyages increases, NSR/SCR-combined shipping by the 4,000 TEU ice-class ship may achieve annual container shipment of 36,400 (TEU/year) [108.3\% of the SCR annual container shipping capacity], 39,200 (TEU/year) [116.7\%] and 42,000 (TEU/year) [125.0\%] respectively for 13, 14 and 15 annual voyages. Additional 
annual shipments of up to $25 \%$ compared to the SCR capacity may attract operators and or ship-owners to consider using the NSR/SCR combined service.

\section{Insert Table 9}

\subsection{Comparison of container transport time}

Transport time via the NSR is estimated to be 19.3 days, 35.4\% faster than that (30.4 days) via the SCR. The reduced transport time via the NSR is a significant advantage against SCR shipping especially for the high-value cargoes.

\subsection{Comparison of reduction effect of $\mathrm{CO}_{2}$ emission}

$\mathrm{CO}_{2}$ emissions are calculated to be $14 \%-35 \%$ less via the NSR due to reduced sailing distance for the NSR service period of 105 days to 225 days assuming that a 4,000 TEU vessel is deployed on the SCR (see Table 10). This may attract the operators and/or ship-owners to operate an NSR/SCR service from the greener shipping viewpoint rather than just the financial one. However, it should be pointed out that operating larger than 4000 TEU vessels on the SCR produces less $\mathrm{CO}_{2}$ emissions per TEU than any of the NSR/SCR scenarios with a 4000 TEU vessel.

\section{Insert Table 10}

\section{Conclusions}

Maritime trade between East Asia and Northwest Europe using the NSR has been increasing recently, because ship operators may take advantage of the shorter sailing distance of NSR, of which navigable season has been made longer due to retreated Arctic sea ice. As the Arctic sea ice continues to retreat due to global warming, the NSR is now approximately $40 \%$ shorter than the SCR for such trade. Various comparative analyses of the estimated shipping costs via the NSR and the alternative conventional routes have been carried out in this paper.

Since assumptions used in the cost estimations vary among the studies as discussed by Lasserre (2014), there remain some difficulties when comparing the estimated shipping costs. This study aims at establishing a common platform of a wide range of cost estimation assumptions through clarifying and analysing cost components contained in the current literature. In addition, interviews with certain NSR shipping professionals were conducted concerning NSR fee on an unofficial basis, since typically such fees are determined based on negotiations between ice breaker escort service provider and a shipping company. An empirical analysis revealed that NSR/SCR-combined shipping of container cargo between East Asia and Northwest Europe can be commercially feasible. 
Based on the base scenario by the 4,000 TEU ice-class ship assuming the NSR service period of 105 days and fuel cost of 650 (USD/ton), NSR/SCR-combined shipping unit cost was calculated at 1,211 (USD/TEU), which is competitive against SCR shipping (1,355 USD/TEU, 1,320 USD/TEU and 1,211 USD/TEU respectively by ordinary 4,000 TEU, 6,000 TEU and 8,000 TEU container ships). However, container ships operated via the SCR between East Asia and Northwest Europe have been rapidly shifting to large (6,000 TEU-8,000 TEU) and/or ultra-large (15,000 TEU) ships, which significantly affect the competitive advantages of NSR/SCR-combined shipping by the 4,000 TEU ice-class ship. On the other hand, when the NSR service period reaches 225 days, NSR/SCR-combined shipping (984USD/TEU) appears nearly competitive against SCR shipping (944USD/TEU) even when an ordinary ultra-large container ship of 15,000TEU is deployed. This also implies that NSR/SCRcombined shipping of container transport by the 4,000TEU ice-class container ship can be regarded as economically feasible to a certain extent, even though SCR shipping deploys large (between 6,000TEU and 8,000TEU) and/or ultra-large container ships (15,000TEU).

NSR/SCR-combined shipping enables 13 to 15 voyages per year depending on the NSR service period (105 days-225 days), while the number of annual voyages is 12 for SCR shipping, achieving annual container shipment of 33,600 (TEU/year) when an ordinary 4,000 TEU ship is deployed. As the number of annual voyages increases, NSR/SCR-combined shipping by the 4,000TEU ice-class ship, annual container shipment of 36,400 (TEU/year) [108.3\%], 39,200 (TEU/year) [116.7\%] and 42,000 (TEU/year) [125.0\%] respectively become possible for 13, 14 and 15 annual voyages. Additional annual shipment of $25 \%$ may seem attractive enough to the operators and/or ship-owners from the financial viewpoint.

Transport time via the NSR is estimated at 19.3 days, 35.4\% faster than that (30.4 days) via the SCR. Reduced transport time is a significant advantage against SCR shipping especially for high-value cargoes.

Assuming the deployment of the same sized 4000 TEU vessel, of the decrease in $\mathrm{CO}_{2}$ emission due to the reduced sailing distance via the NSR ranges from $14 \%$ to $35 \%$. This may attract the operators and/or ship-owners from the greener shipping viewpoint rather than the financial viewpoint.

Cost analysis of NSR/SCR-combined shipping for the various scenarios may provide valuable insights to the researcher as well as practitioners. Based on the common platform provided by this research, it is hoped that various related research topics will be undertaken.

\section{Acknowledgements}

This study is largely based on "Effects of the Arctic Sea Routes (NSR and NWP) Navigability on Port Industry” (Project period: 2011-2013), funded by International Association of Ports 
and Harbors (IAPH). Our special thanks first go to IAPH and all the committee members of the Port Planning and Development Committee (PPDC) of IAPH.

Furthermore, the authors present special thanks to Mr. Mitsuhiko Okada, the President, Overseas Coastal Development Institute (OCDI), Japan for his insight and useful comments.

\section{References}

Arpiainen, M. and Killi, R. (2006) Arctic shuttle container link from Alaska US and Europe, Report K-63: Aker Arctic Technology Inc., Helsinki, Finland.

Falck, H. (2012) Shipping in Arctic Waters -The Northern Sea Route-: Mariehamn, Finland available at http://www.sjofart.ax/files/henrik_falck_shipping_in_arctic_waters.pdf accessed 2 April 2014

Furuichi, M. and Otsuka, N. (2012) Effects of the Arctic Sea Routes (NSR and NWP) Navigability on Port Industry, 21 May, Jerusalem, Israel, Presentation at Port Planning and Development Committee (PPDC), International Association of Ports and Harbors (IAPH).

Hino, M. (2011) Progress of maritime shipping industry and current situation: Financial Department of Ehime Bank (in Japanese).

IMO (2009) Second IMO GHG Study 2009: London, U.K.

Isakov, N. A., et al (1999) The NSR Simulation Study Package 3: Potential Cargo Flow Analysis and Economic Evaluation for the Simulation Study (Russian Part), INSROP Working Paper No. 139.

Japan Ship-owners Association (2012) Shipping Fact 2012 (in Japanese), http://www.jsanet.or.jp/data/pdf/data1_2012b.pdf, accessed 21 December.

Lasserre, F. (2014) Case studies of shipping along Arctic routes. Analysis and profitability perspectives for the container sector, Transportation Research Part A, 66, pp.144-161.

Liu, M. and Kronbak, J. (2010) The potential economic viability of using the Northern Sea Route (NSR) as an alternative route between Asia and Europe, Journal of Transport Geography, No.18, pp.434-444.

Maritime Press Japan (2012) Transactions of newly built merchant fleet in 2012 (1), (in Japanese), 10 December.

Maritime Press Japan (2012) Transactions of newly built merchant fleet in 2012 (2), (in Japanese, 10 December.

MOL (2012) http://www.moljapan.co.jp/service/ex_charge/eur.shtml, accessed 21 December. 
Omre A. (2012) An economic transport system of the next generation integrating the northern and southern passage, Master Thesis, Norwegian University of Science and Technology, Trondheim, Norway.

Panama Canal Authority (2012) http://www.pancanal.com/eng/maritime/tolls.html, accessed 21 December.

Ragner, C. L. (2000) Northern Sea Route Cargo Flows and Infrastructure - Present State and Future Potential, FNI Report 13, Fridtjof Nansen Institute, Lysaker, Norway.

Russian Federal Law of July 28, 2012 (2012) "On Amendments to Certain Legislative Acts of the Russian Federation Concerning State Regulation of Merchant Shipping on the Water Area of the Northern Sea Route", Article 3 section 5,retrieved from "http://www.nsra.ru/en/zakon_o_smp/” on March 2014.

Russian Ministry of Justice (2014) Federal Service for Tariffs, Order of March 4, 2014, N 45 t/1, About the Approval of Tariffs for the Ice breaker Escorting of Ships rendered by FSUE "ATOMFLOT" in the Water Area of the Northern Sea Route, retrieved from "http://www.nsra.ru/en/tarrifs_for_icebreaker_escort_atomflot/” on March 2014.

Schoyen, H. and Brathen, S. (2011) The Northern Sea Route versus the Suez Canal: cases from bulk shipping, Journal of Transport Geography, No. 19, pp.977-983.

Ship \& Ocean Foundation (2000) The Northern Sea Route -The Shortest sea route linking East Asia and Europe, Tokyo, Japan.

Suez Canal Authority (2012) http://www.suezcanal.gov.eg/TollCirculars.aspx, accessed 21 December.

UNCTAD (2011) Review of Maritime Transport 2011: Geneva, Switzerland.

Verny, J. and Grigentin, C. (2009) Container shipping on the Northern Sea Route, International Journal of Production Economics, No.122, pp. 107-117.

Yakovlev, A., et al (1999) The NSR Simulation Study Package 7: Legal and Environmental Evaluation of the Routes Selected for the INSROP Simulation Study, INSROP Working Paper No. 128. 


\section{Tables and Figures}

Table 1 Maritime shipping cost components (examples)

\begin{tabular}{|l|l|}
\hline Operator's viewpoint & Ship-owner's viewpoint \\
\hline Capital cost & Depreciation cost \\
\hline NSR fee & NSR fee \\
\hline Ice pilot fee & Ice pilot fee \\
\hline Suez Canal fee & Suez Canal fee \\
\hline Crew cost & Crew cost \\
\hline Maintenance cost & Maintenance cost \\
(Article cost of ship, Lubricant cost, Dock & (Article cost of ship, Lubricant cost, Dock \\
cost, and Maintenance and spare parts cost) & cost, and Maintenance and spare parts cost) \\
\hline $\begin{array}{l}\text { Insurance cost } \\
\text { (H\&M insurance and P\&I insurance) }\end{array}$ & $\begin{array}{l}\text { Insurance cost } \\
\text { (H\&M insurance and P\&I insurance) }\end{array}$ \\
\hline Fuel cost & Fuel cost \\
\hline Port dues & Port dues \\
\hline & Miscellaneous cost, Administration cost and \\
& Interest fee \\
\hline
\end{tabular}

Source: Clarified by the authors referring to Ship \& Ocean Foundation (2000) and Hino (2011)

Table 2 Building costs of various types of the ordinary new ships based on actual transactions in 2012

\begin{tabular}{|l|l|l|c|}
\hline \multirow{2}{*}{ Ship type } & Applicable routes & \multicolumn{1}{|c|}{ Ship size } & $\begin{array}{c}\text { Ship building cost } \\
\text { (million USD) }\end{array}$ \\
\hline \multirow{4}{*}{ Container ship } & NSR/SCR & 4,000 TEU & 47.0 \\
\cline { 2 - 4 } & SCR & 6,000 TEU & 67.4 \\
\cline { 2 - 4 } & SCR & 8,000 TEU & 87.9 \\
\cline { 2 - 4 } & SCR & 15,000 TEU & 159.4 \\
\hline LNG ship & NSR/SCR & $150,000 \mathrm{m3}$ & 200.0 \\
\hline PCC ship & NSR/SCR & 6,500 CEU & 68.3 \\
\hline \multirow{2}{*}{ Dry bulk ship } & NSR/SCR & 75,000 DWT & 33.5 \\
\cline { 2 - 4 } & SCR/Cape Route/Panama & 170,000 DWT & 58.2 \\
\hline
\end{tabular}

Source: Determined by the authors analyzing the recent transactions reported in Maritime Press Japan (2012) and UNCTAD (2011) 
Table 3 Suez Canal fees (as of December 2012)

\begin{tabular}{|c|c|c|c|c|c|c|c|c|c|c|c|c|c|c|c|}
\hline \multirow{3}{*}{\multicolumn{2}{|c|}{ Ship Type }} & \multicolumn{11}{|c|}{ SC Net Tonnage (SCNT) } & \multicolumn{3}{|c|}{ (Unit: SDR / SCNT) } \\
\hline & & \multicolumn{2}{|c|}{ First $\mathbf{5 0 0 0}$} & \multicolumn{2}{|c|}{ Next 5000} & \multicolumn{2}{|c|}{ Next 10000} & \multicolumn{2}{|c|}{ Next 20000} & \multicolumn{2}{|c|}{ Next 30000} & \multicolumn{2}{|c|}{ Next 50000} & \multicolumn{2}{|c|}{ Rest } \\
\hline & & Laden & Ballast & Laden & Ballast & Laden & Ballast & Laden & Ballast & Laden & Ballast & Laden & Ballast & Laden & Ballast \\
\hline 1 & Tankers of Crude Oil & 7.88 & 6.70 & 5.58 & 4.74 & 4.22 & 3.59 & 1.84 & 1.56 & 1.63 & 1.39 & 1.51 & 1.28 & 1.41 & 1.20 \\
\hline 2 & $\begin{array}{l}\text { Tankers of } \\
\text { Petroleum Products }\end{array}$ & 7.88 & 6.70 & 5.58 & 4.74 & 4.22 & 3.59 & 2.54 & 1.56 & 2.49 & 1.39 & 2.38 & 1.28 & 2.27 & 1.20 \\
\hline 3 & Dry Bulk Carriers & 7.88 & 6.70 & 6.02 & 5.12 & 4.76 & 4.05 & 1.51 & 1.28 & 1.41 & 1.20 & 1.35 & 1.15 & 1.30 & 1.11 \\
\hline 4 & LPG Carriers & 7.88 & 6.70 & 5.70 & 4.85 & 4.22 & 3.59 & 3.02 & 2.57 & 2.81 & 2.39 & 2.71 & 2.30 & 2.71 & 2.30 \\
\hline 5 & LNG Carriers & 7.88 & 6.70 & 6.13 & 5.21 & 5.30 & 4.51 & 3.68 & 3.13 & 3.57 & 3.03 & 3.47 & 2.95 & 3.35 & 2.85 \\
\hline 6 & $\begin{array}{l}\text { Chemical Carriers \& } \\
\text { Other Liquid bulk } \\
\text { Carriers }\end{array}$ & 8.24 & 7.00 & 6.37 & 5.41 & 5.08 & 4.32 & 3.24 & 2.75 & 3.14 & 2.67 & 3.02 & 2.57 & 3.02 & 2.57 \\
\hline 7 & Containerships & 7.88 & 6.70 & 5.41 & 4.60 & 4.20 & 3.57 & 2.94 & 2.50 & 2.73 & 2.32 & 2.15 & 1.83 & 2.05 & 1.74 \\
\hline 8 & General Cargo Ships & 7.88 & 6.70 & 6.08 & 5.17 & 4.24 & 3.60 & 3.18 & 2.70 & 3.08 & 2.62 & 3.03 & 2.58 & 2.97 & 2.52 \\
\hline 9 & Ro/Ro Ships & 7.88 & 6.70 & 5.86 & 4.98 & 4.56 & 3.88 & 3.29 & 2.80 & 3.08 & 2.62 & 2.97 & 2.52 & 2.86 & 2.43 \\
\hline 10 & Vehicle Carriers & 7.88 & 6.70 & 5.41 & 4.60 & 4.05 & 3.44 & 2.89 & 2.46 & 2.73 & 2.32 & 2.15 & 1.83 & 2.05 & 1.74 \\
\hline 11 & Passenger Ships & 7.88 & 6.70 & 5.54 & 4.71 & 4.56 & 3.88 & 3.23 & 2.75 & 3.18 & 2.70 & 3.08 & 2.62 & 2.97 & 2.52 \\
\hline 12 & $\begin{array}{l}\text { Special Floating } \\
\text { Units }\end{array}$ & 8.55 & - & 5.66 & - & 5.09 & - & 3.61 & - & 3.40 & - & 3.08 & - & 2.97 & - \\
\hline 13 & Other Vessels & 8.24 & 7.00 & 5.55 & 4.72 & 4.67 & 3.97 & 3.40 & 2.89 & 3.29 & 2.80 & 3.08 & 2.62 & 2.97 & 2.52 \\
\hline
\end{tabular}

Remarks: SDR stands for Special Drawing Right.

Source: Suez Canal Authority (2012), http://www.suezcanal.gov.eg/TollCirculars.aspx, accessed 21

December, 2012.

Table 4 Panama Canal fees (as of December 2012)

(Unit: USD/PC UMS)

\begin{tabular}{|l|c|c|c|c|}
\hline \multirow{2}{*}{ Ship type } & Loading Conditions & \multicolumn{3}{|c|}{ Panama Canal fee } \\
\hline \multirow{2}{*}{ Container } & Laden & \multicolumn{3}{|c|}{72.0 USD/TEU } \\
\cline { 2 - 5 } & Ballast & \multicolumn{3}{|c|}{57 USD/TEU } \\
\hline \multirow{2}{*}{ Ship type/PC UMS } & PC UMS (ton) & $0-10,000$ & $10,000-20,000$ & $20,000+$ \\
\hline \multirow{2}{*}{ Dry Bulk } & Laden & 4.74 & 4.64 & 4.57 \\
\cline { 2 - 5 } & Ballast & 3.79 & 3.72 & 3.66 \\
\hline \multirow{2}{*}{ Tanker } & Laden & 4.71 & 4.55 & 4,47 \\
\hline \multirow{2}{*}{ Chemical Tanker } & Ballast & 3.76 & 3.63 & 3.58 \\
\cline { 2 - 5 } & Laden & 4.68 & 4.61 & 4.53 \\
\hline \multirow{2}{*}{ LPG } & Ballast & 3.75 & 3.69 & 3.62 \\
\cline { 2 - 5 } & Laden & 4.82 & 4.74 & 4.65 \\
\hline \multirow{2}{*}{ Vehicle Carriers/RoRo } & Ballast & 3.86 & 3.79 & 3.73 \\
\cline { 2 - 5 } & Laden & 4.75 & 4.68 & 4.59 \\
\hline \multirow{2}{*}{ Others } & Ballast & 3.84 & 3.77 & 3.71 \\
\cline { 2 - 5 } & Laden & 4.40 & 4.31 & 4.24 \\
\cline { 2 - 5 } & Ballast & 3.52 & 3.45 & 3.40 \\
\hline
\end{tabular}

Source: Panama Canal Authority (2012), http://www.pancanal.com/eng/maritime/tolls.html, accessed 21 December, 2012. 
Table 5 NSR/SCR-combined shipping scenarios

1. Origin and Destination: Yokohama port (Japan) and Hamburg port (Germany)

\begin{tabular}{|c|c|c|c|c|c|c|c|c|}
\hline \multicolumn{8}{|c|}{ 2. NSR Service-period } & (unit: days) \\
\hline & May & June & July & Aug. & Sep. & Oct. & Nov. & Dec. \\
\hline \multirow{2}{*}{$\begin{array}{l}\text { Operational } \\
\text { Sailing Speed } \\
\text { (knot) }\end{array}$} & \multicolumn{3}{|c|}{12.8 knots (Ice waters) } & \multicolumn{3}{|c|}{14.1 knots (Ice waters) } & \multicolumn{2}{|c|}{$\begin{array}{c}12.8 \text { knots (Ice } \\
\text { waters) }\end{array}$} \\
\hline & \multicolumn{8}{|c|}{20.0 knots (Ordinary waters) } \\
\hline 105 days & --- & --- & --- & 30 & 30 & 30 & 15 & --- \\
\hline 135 days & --- & --- & 15 & 30 & 30 & 30 & 30 & --- \\
\hline 165 days & --- & 15 & 30 & 30 & 30 & 30 & 30 & --- \\
\hline 195 days & --- & 30 & 30 & 30 & 30 & 30 & 30 & 15 \\
\hline 225 days & 15 & 30 & 30 & 30 & 30 & 30 & 30 & 30 \\
\hline
\end{tabular}

\begin{tabular}{|c|c|c|c|c|c|c|c|c|}
\hline 3. Principal Characteristics of container ship for NSR/SCR-combined shipping scenarios \\
\hline Ship-size & Route & Crew & $\begin{array}{c}\text { LOA } \\
(\mathrm{m})\end{array}$ & $\begin{array}{c}\text { Beam } \\
(\mathrm{m})\end{array}$ & $\begin{array}{c}\text { Draft } \\
(\mathrm{m})\end{array}$ & $\begin{array}{c}\text { GT } \\
(\text { ton })\end{array}$ & $\begin{array}{c}\text { Nominal } \\
\text { Speed } \\
(\mathrm{knots})\end{array}$ & $\begin{array}{c}\text { Engine } \\
\text { Power } \\
(\mathrm{kW})\end{array}$ \\
\hline 4,000TEU & NSR/SCR & 23 & 296 & 32 & 13.0 & 40,000 & 25 & 40,000 \\
\hline 6,000TEU & SCR & 23 & 296 & 40 & 14.0 & 75,000 & 25 & 57,000 \\
\hline 8,000TEU & SCR & 23 & 323 & 43 & 14.5 & 89,000 & 25 & 68,000 \\
\hline 15,000TEU & SCR & 23 & 397 & 56 & 15.5 & 155,000 & 25 & 80,000 \\
\hline
\end{tabular}

4. Fuel consumption premium of ice-class ship is set at $10 \%$.

5. Special Fuel Oil Consumption (SFOC) is set at $185(\mathrm{~g} / \mathrm{kWh})$.

6. Additional building cost of ice-class ship is set at $10 \%$. 
Table 6 Practical level of cost components

\begin{tabular}{|c|c|}
\hline Cost component & Description \\
\hline 1. Capital cost & $\begin{array}{l}\text { Capital cost is introduced as a yearly repayment (i.e. equivalent to a repayment of } 10.9 \% \\
\text { of the capital cost for } 15 \text { years) of the new ship based on an interest rate of } 7 \% \text { and a } \\
\text { return period of } 15 \text { years, from the project finance viewpoint (Ship \& Ocean Foundation } \\
(2000) \text { ). }\end{array}$ \\
\hline 2. NSR fee & $\begin{array}{l}\text { NSR fee is assumed to be } 5.0 \text { (USD/GT) which is the latest report of NSR fee transaction } \\
\text { (Falck (2012)). }\end{array}$ \\
\hline 3. Ice pilot fee & $\begin{array}{l}\text { Ice pilot fee is assumed } 673 \text { (USD/day) for the NSR navigation between Kara and Bering } \\
\text { straits, as stipulated by the Russian regulation. }\end{array}$ \\
\hline 4. SCR fee & $\begin{array}{l}\text { Suez Canal fees are taken from the website of the Suez Canal Authority as of December } \\
2012 .\end{array}$ \\
\hline 5. Crew cost & $\begin{array}{l}\text { Crew cost is assumed } 1.0 \text { million (USD/ship/year), as Japan Ship-owners Association [JSA] } \\
\text { (2012) reported. }\end{array}$ \\
\hline 6. Maintenance cost & $\begin{array}{l}\text { An annual maintenance cost is proportionally assumed } 1.095 \text { (\%/year) of the ship } \\
\text { building cost, as reported by Hino (2011). }\end{array}$ \\
\hline 7. Insurance cost & $\begin{array}{l}\text { Annual insurance premium of both } \mathrm{H} \& \mathrm{M} \text { and } \mathrm{P} \& \mathrm{I} \text { insurance in total is proportionally } \\
\text { assumed } 0.343 \text { (\%/year) of the ship building cost, as reported by Hino (2011). Annual } \\
\text { insurance premium of } 10 \text { (USD/GT/year) in total is assumed as additional H\&M and P\&l } \\
\text { insurance premium for the NSR shipping, as reported by Ship \& Ocean Foundation [SOF], } \\
\text { (2000). Apart from the ordinary insurance cost, Aden Emergency Charge (40USD/TEU) is } \\
\text { similarly assumed for the SCR shipping as a kind of insurance premium for piracy off } \\
\text { Somalia, as stipulated by MOL (2012). }\end{array}$ \\
\hline 8. Fuel cost & $\begin{array}{l}\text { Fuel unit cost is assumed between } 300 \text { and } 900 \text { (USD/ton), taking the recent transactions } \\
\text { in Singapore into account. The assumption that fuel consumption per distance unit is } \\
\text { proportional to the square of sailing speed is recommended to be applied in the } \\
\text { calculation, when operational sailing speed is slower in the ice waters for the NSR } \\
\text { shipping. }\end{array}$ \\
\hline 9. Port dues & $\begin{array}{l}\text { Port dues are assumed to be } 0.428 \text { (USD/GT/call) in total for each port entry, including } \\
\text { port entry due, berthing due and line-handling charge. Additionally, container handling } \\
\text { charge of } 100 \text { (USD/TEU) is assumed for loading and unloading respectively at both end } \\
\text { ports. }\end{array}$ \\
\hline
\end{tabular}


Table 7 Cost component breakdown by NSR fee for the basic scenario

\begin{tabular}{|l|c|c|}
\hline $\begin{array}{l}\text { Ship-size / 4,000 TEU } \\
\begin{array}{l}\text { NSR service-period } \\
\text { SCR service-period }\end{array}\end{array}$ & $\begin{array}{l}\text { NSR fee: } 5.0 \text { (USD/GT) } \\
\text { NSR } 105 \text { days } \\
\text { SCR 260 days }\end{array}$ & $\begin{array}{l}\text { NSR fee: } 979 \text { (USD/TEU) } \\
\text { NSR } 105 \text { days } \\
\text { SCR 260 days }\end{array}$ \\
\hline Annual container throughput & 36,400 (TEU/year) & 36,400 (TEU/year) \\
\hline Shipping unit cost per TEU & 1,211 (USD/TEU) & 2,183 (USD/TEU) \\
\hline Annual voyages & NSR: 5 / SCR: 8 & NSR: 5 / SCR: 8 \\
\hline Depreciation cost & $4,925(11.2 \%)$ & $4,925(6.2 \%)$ \\
\hline $\begin{array}{l}\text { NSR fee, NSR pilot fee, NSR insurance } \\
\text { premium }\end{array}$ & $1,433(3.3 \%)$ & $36,804(46.3 \%)$ \\
\hline $\begin{array}{l}\text { Suez Canal fee, Suez insurance premium, } \\
\text { Aden emergency charge }\end{array}$ & $3,115(7.1 \%)$ & $3,115(3.9 \%)$ \\
\hline Crew cost & $954(2.2 \%)$ & $954(1.2 \%)$ \\
\hline Maintenance cost & $491(1.1 \%)$ & $491(0.6 \%)$ \\
\hline Insurance cost & $154(0.3 \%)$ & $154(0.2 \%)$ \\
\hline Fuel cost & $24,196(54.9 \%)$ & $24,196(30.5 \%)$ \\
\hline $\begin{array}{l}\text { Port dues including container handling } \\
\text { charge }\end{array}$ & $8,822(20.0 \%)$ & $8,822(11.1 \%)$ \\
\hline Grand total & $44,086(100 \%)$ & $79,461(100 \%)$ \\
\hline
\end{tabular}

Table 8 Shipping unit cost by ship-size assuming fuel costs of 300USD/ton, 650USD/ton and 900USD/ton

\begin{tabular}{|l|c|c|c|c|c|}
\hline Ship-size/ & 4,000 TEU & 4,000 TEU & 6,000 TEU & 8,000 TEU & 15,000 TEU \\
NSR service-period & NSR 105days & NSR 0 day & NSR 0 day & NSR 0 day & NSR 0 day \\
SCR service-period & SCR 260days & SCR 365days & SCR 365days & SCR 365days & SCR 365days \\
\hline Annual voyages & NSR: 5 & NSR: 0 & NSR: 0 & NSR: 0 & NSR: 0 \\
& SCR: 8 & SCR: 12 & SCR: 12 & SCR: 12 & SCR: 12 \\
\hline Fuel cost: & 856 & 945 & 930 & 862 & 726 \\
300USD/ton & (USD/TEU) & (USD/TEU) & (USD/TEU) & (USD/TEU) & (USD/TEU) \\
\hline Fuel cost: & 1,211 & 1,355 & 1,320 & 1,211 & 944 \\
650USD/ton & (USD/TEU) & (USD/TEU) & (USD/TEU) & (USD/TEU) & (USD/TEU) \\
\hline Fuel cost: & 1,464 & 1,648 & 1,598 & 1,459 & 1,110 \\
900USD/ton & (USD/TEU) & (USD/TEU) & (USD/TEU) & (USD/TEU) & (USD/TEU) \\
\hline
\end{tabular}


Table 9 Annual container shipping capacity by the NSR service period

\begin{tabular}{|c|c|c|c|c|c|c|}
\hline \multicolumn{7}{|c|}{ (Unit: USD/TEU) } \\
\hline \begin{tabular}{|c|} 
Ship-size/ \\
NSR service-period \\
SCR service-period
\end{tabular} & $\begin{array}{c}\text { 4,000 TEU } \\
\text { NSR Oday } \\
\text { SCR 365days }\end{array}$ & $\begin{array}{c}\text { 4,000 TEU } \\
\text { NSR 105days } \\
\text { SCR 260days }\end{array}$ & \begin{tabular}{|c|} 
4,000 TEU \\
NSR 135days \\
SCR 230days
\end{tabular} & $\begin{array}{c}\text { 4,000 TEU } \\
\text { NSR } 165 \text { days } \\
\text { SCR 200days }\end{array}$ & \begin{tabular}{|c|} 
4,000 TEU \\
NSR 195days \\
SCR 170days
\end{tabular} & \begin{tabular}{|c|} 
4,000 TEU \\
NSR 225days \\
SCR 140days
\end{tabular} \\
\hline Annual voyages & $\begin{array}{c}12 \text { in total } \\
\text { NSR: } 0 \\
\text { SCR: } 12 \\
\end{array}$ & $\begin{array}{l}13 \text { in total } \\
\text { NSR: } 5 \\
\text { SCR: } 8\end{array}$ & $\begin{array}{l}14 \text { in total } \\
\text { NSR: } 6 \\
\text { SCR: } 8\end{array}$ & $\begin{array}{c}14 \text { in total } \\
\text { NSR: } 8 \\
\text { SCR: } 6\end{array}$ & $\begin{array}{l}15 \text { in total } \\
\text { NSR: } 9 \\
\text { SCR: } 6\end{array}$ & $\begin{array}{l}15 \text { in total } \\
\text { NSR: } 11 \\
\text { SCR: } 4\end{array}$ \\
\hline $\begin{array}{l}\text { Annual container } \\
\text { shipment capacity }\end{array}$ & $\begin{array}{c}33,600 \\
{[100 \%]} \\
\text { (TEU/year) }\end{array}$ & $\begin{array}{c}\text { 36,400 } \\
{[108.3 \%]} \\
\text { (TEU/year) }\end{array}$ & $\begin{array}{c}\text { 39,200 } \\
{[108.3 \%]} \\
\text { (TEU/year) }\end{array}$ & $\begin{array}{c}39,200 \\
{[116.7 \%]} \\
\text { (TEU/year) }\end{array}$ & $\begin{array}{c}42,000 \\
{[116.7 \%]} \\
\text { (TEU/year) }\end{array}$ & $\begin{array}{c}42,000 \\
{[125 \%]} \\
\text { (TEU/year) }\end{array}$ \\
\hline
\end{tabular}

Table $10 \mathrm{CO}_{2}$ unit emission per TEU by ship-size and the NSR service period

\begin{tabular}{|c|c|c|c|c|c|}
\hline \multicolumn{6}{|c|}{ (Unit: $\mathrm{CO}_{2}$ ton/TEU) } \\
\hline $\begin{array}{l}\text { Ship-size/ } \\
\text { NSR service-period } \\
\text { SCR service-period }\end{array}$ & $\begin{array}{l}\text { 4,000 TEU } \\
\text { NSR 105days } \\
\text { SCR 260days }\end{array}$ & $\begin{array}{l}\text { 4,000 TEU } \\
\text { NSR } 0 \text { day } \\
\text { SCR 365days }\end{array}$ & $\begin{array}{l}\text { 6,000 TEU } \\
\text { NSR } 0 \text { day } \\
\text { SCR 365days }\end{array}$ & $\begin{array}{l}\text { 8,000 TEU } \\
\text { NSR } 0 \text { day } \\
\text { SCR 365days }\end{array}$ & $\begin{array}{l}\text { 15,000 TEU } \\
\text { NSR } 0 \text { day } \\
\text { SCR 365days }\end{array}$ \\
\hline $\begin{array}{l}\text { NSR 105days } \\
\text { SCR 260days }\end{array}$ & $\begin{array}{c}1.023[86.5 \%] \\
\text { (ton/TEU) }\end{array}$ & \multirow{5}{*}{$\begin{array}{c}1.182 \\
{[100 \%]} \\
\text { (ton/TEU) }\end{array}$} & \multirow{5}{*}{$\begin{array}{c}0.733 \\
{[62.0 \%]} \\
\text { (ton/TEU) }\end{array}$} & \multirow{5}{*}{$\begin{array}{c}0.656 \\
{[55.5 \%]} \\
\text { (ton/TEU) }\end{array}$} & \multirow{5}{*}{$\begin{array}{c}0.412 \\
{[34.9 \%]} \\
\text { (ton/TEU) }\end{array}$} \\
\hline $\begin{array}{l}\text { NSR 135days } \\
\text { SCR 230days }\end{array}$ & $\begin{array}{c}0.992 \text { [83.9\%] } \\
\text { (ton/TEU) }\end{array}$ & & & & \\
\hline $\begin{array}{l}\text { NSR 165days } \\
\text { SCR 200days }\end{array}$ & $\begin{array}{c}0.889[75.2 \%] \\
\text { (ton/TEU) }\end{array}$ & & & & \\
\hline $\begin{array}{l}\text { NSR 195days } \\
\text { SCR 170days }\end{array}$ & $\begin{array}{c}0.868[73.4 \%] \\
\text { (ton/TEU) }\end{array}$ & & & & \\
\hline $\begin{array}{l}\text { NSR 225days } \\
\text { SCR 140days }\end{array}$ & $\begin{array}{c}0.772[65.3 \%] \\
\text { (ton/TEU) }\end{array}$ & & & & \\
\hline
\end{tabular}




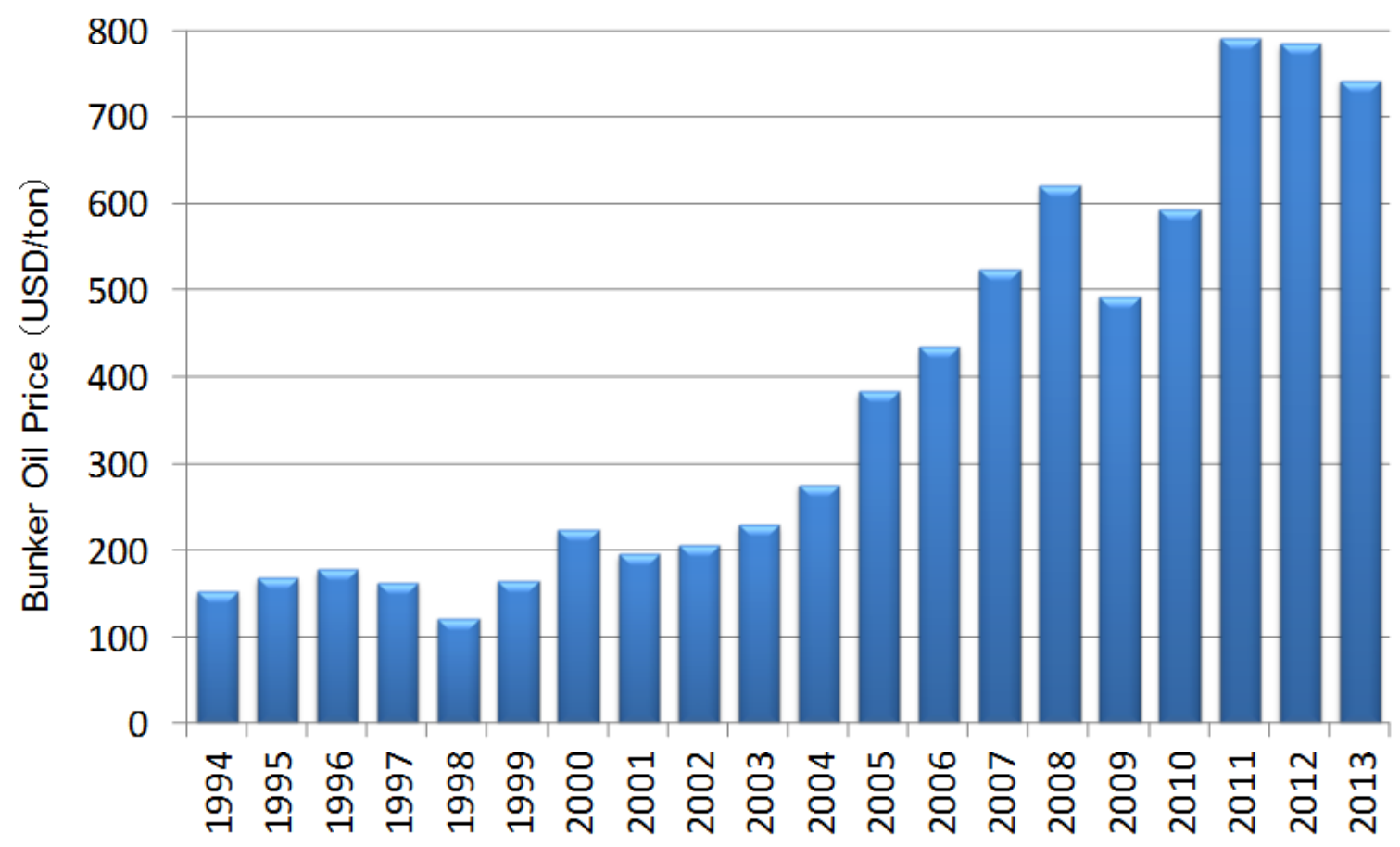

Source: Japan Long Course Ferry Service Association (http://www.jlc-ferry.jp/nenryouyu.html)

Figure 1 Bunker oil prices for the last twenty years

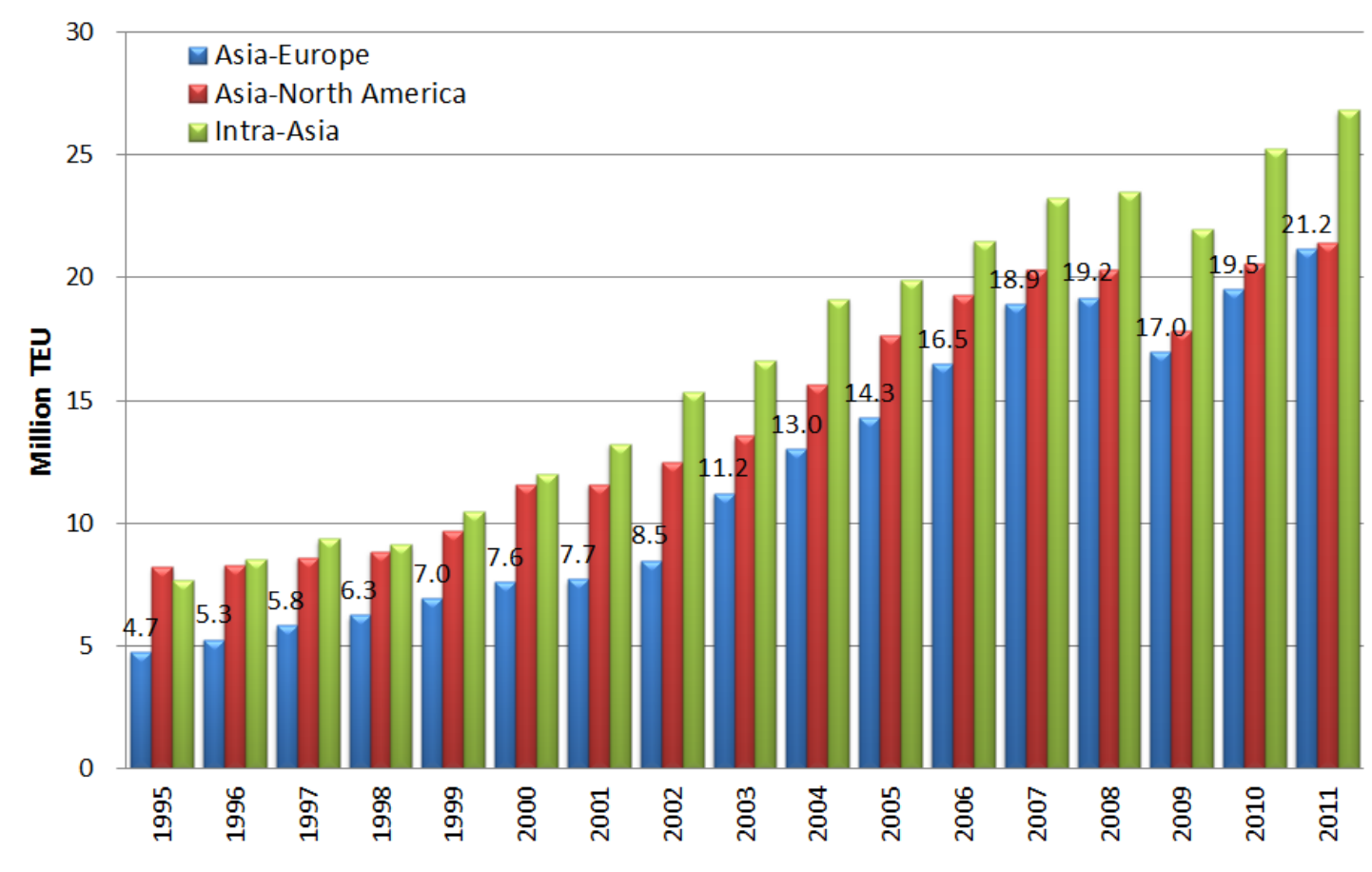

Source) Japan Marine Center (http://jpmac.or.jp/relation/transport_graph/2_1.pdf)

Figure 2 World Container Flow between Major Regions (1995-2011) 


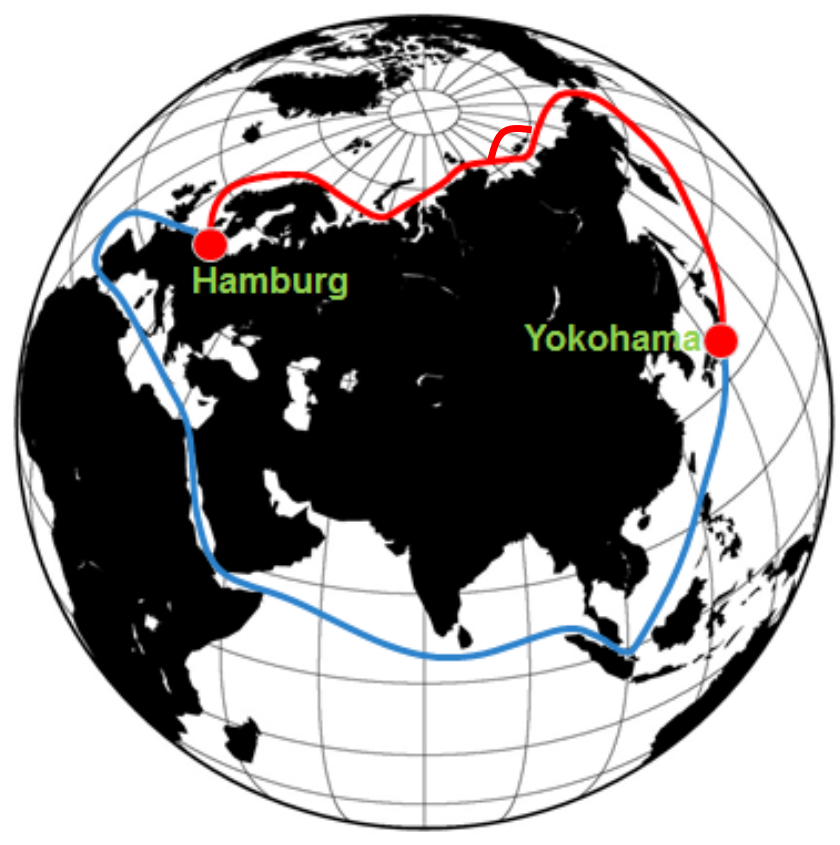

Figure 3 Comparative routes for the NSR and SCR shipping in the scenarios

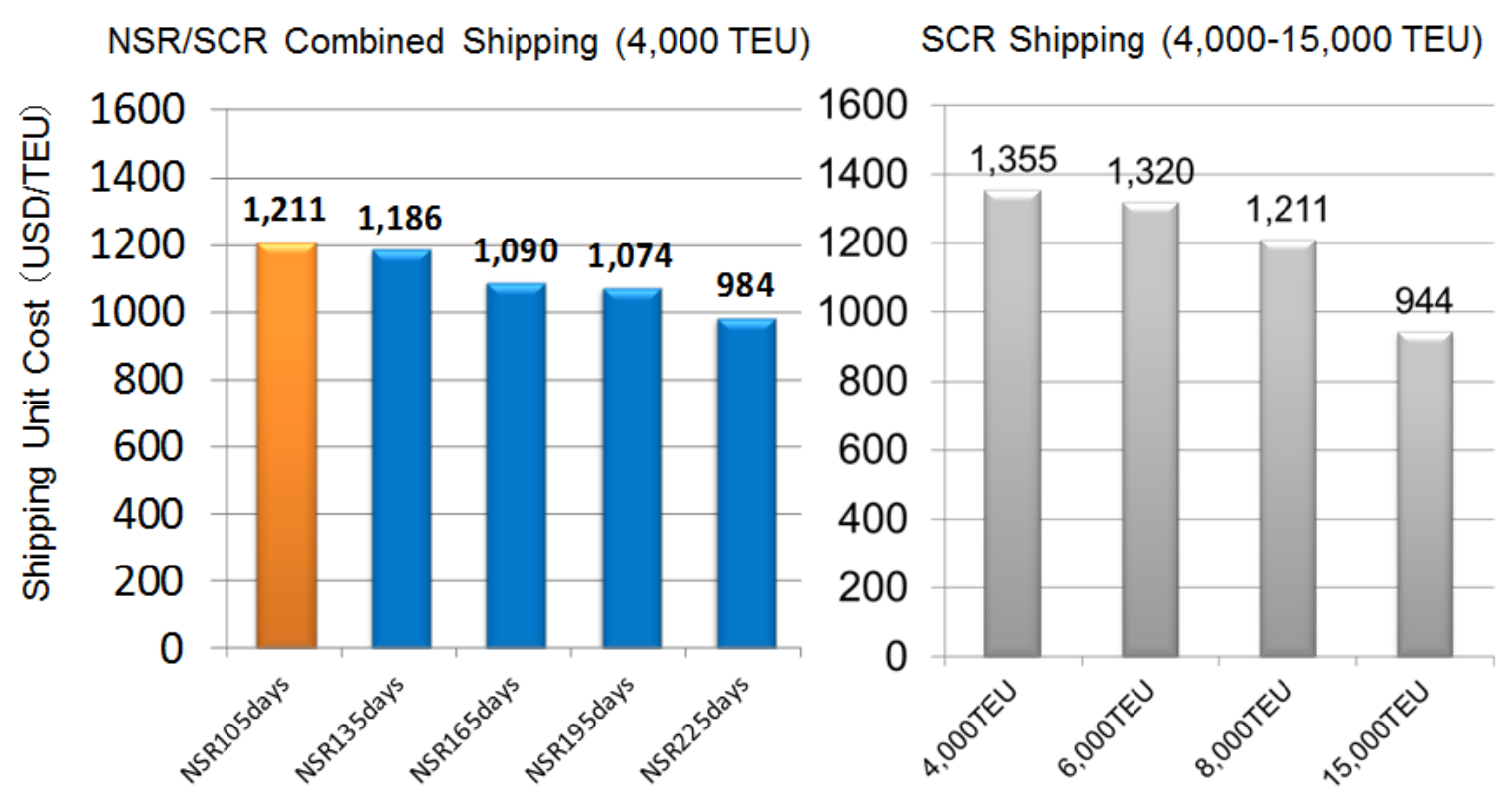

Figure 4 Shipping unit cost of container transport of NSR/SCR-combined shipping and SCR shipping with various NSR service periods 
Appendix

Table A.1 Cost component breakdown by ship-size

\begin{tabular}{|c|c|c|c|c|c|}
\hline \multicolumn{6}{|c|}{ Unit (Upper: '000 USD/year, Lower: \%) } \\
\hline $\begin{array}{l}\text { Ship-size/ } \\
\text { NSR service-period } \\
\text { SCR service-period }\end{array}$ & $\begin{array}{l}\text { 4,000 TEU } \\
\text { NSR 105days } \\
\text { SCR 260days }\end{array}$ & $\begin{array}{l}\text { 4,000 TEU } \\
\text { NSR } 0 \text { day } \\
\text { SCR 365days }\end{array}$ & $\begin{array}{l}\text { 6,000 TEU } \\
\text { NSR } 0 \text { day } \\
\text { SCR 365days } \\
\end{array}$ & $\begin{array}{l}\text { 8,000 TEU } \\
\text { NSR } 0 \text { day } \\
\text { SCR 365days }\end{array}$ & $\begin{array}{l}\text { 15,000 TEU } \\
\text { NSR } 0 \text { day } \\
\text { SCR 365days } \\
\end{array}$ \\
\hline $\begin{array}{l}\text { Annual container } \\
\text { throughput }\end{array}$ & $\begin{array}{c}36,400 \\
\text { (TEU/year) }\end{array}$ & $\begin{array}{c}33,600 \\
\text { (TEU/year) }\end{array}$ & $\begin{array}{c}50,400 \\
\text { (TEU/year) }\end{array}$ & $\begin{array}{c}67,200 \\
\text { (TEU/year) }\end{array}$ & $\begin{array}{c}126,000 \\
\text { (TEU/year) }\end{array}$ \\
\hline $\begin{array}{l}\text { Shipping unit cost per } \\
\text { TEU }\end{array}$ & $\begin{array}{c}1,211 \\
\text { (USD/TEU) }\end{array}$ & $\begin{array}{c}1,355 \\
\text { (USD/TEU) }\end{array}$ & $\begin{array}{c}1,320 \\
\text { (USD/TEU) }\end{array}$ & $\begin{array}{c}1,211 \\
\text { (USD/TEU) }\end{array}$ & $\begin{array}{c}944 \\
\text { (USD/TEU) }\end{array}$ \\
\hline Annual voyages & $\begin{array}{l}\text { NSR: } 5 \\
\text { SCR: } 8\end{array}$ & SCR: 12 & SCR: 12 & SCR: 12 & SCR: 12 \\
\hline Capital cost & $\begin{array}{c}4,925 \\
(11.2 \%)\end{array}$ & $\begin{array}{c}4,688 \\
(10.3 \%)\end{array}$ & $\begin{array}{c}6,728 \\
(10.1 \%)\end{array}$ & $\begin{array}{c}8,769 \\
(10.8 \%)\end{array}$ & $\begin{array}{l}15,909 \\
(13.4 \%)\end{array}$ \\
\hline $\begin{array}{l}\text { NSR fee, Ice pilot fee, } \\
\text { NSR insurance premium }\end{array}$ & $\begin{array}{c}1,433 \\
(3.3 \%)\end{array}$ & $\begin{array}{c}0 \\
0 \\
(0 \%)\end{array}$ & $\begin{array}{c}0 \\
0 \%)\end{array}$ & $\begin{array}{c}0 \\
0 \%)\end{array}$ & $\begin{array}{c}0 \\
(0 \%)\end{array}$ \\
\hline $\begin{array}{l}\text { Suez Canal fee, Suez } \\
\text { insurance premium, } \\
\text { Aden emergency charge }\end{array}$ & $\begin{array}{l}3,115 \\
(7.1 \%)\end{array}$ & $\begin{array}{c}4,572 \\
(10.0 \%)\end{array}$ & $\begin{array}{c}7,099 \\
(10.7 \%)\end{array}$ & $\begin{array}{c}8,387 \\
(10.3 \%)\end{array}$ & $\begin{array}{l}14,208 \\
(11.9 \%)\end{array}$ \\
\hline Crew cost & $\begin{array}{c}954 \\
(2.2 \%)\end{array}$ & $\begin{array}{c}997 \\
(2.2 \%)\end{array}$ & $\begin{array}{c}997 \\
(2.2 \%)\end{array}$ & $\begin{array}{c}997 \\
(2.2 \%)\end{array}$ & $\begin{array}{c}997 \\
(2.2 \%)\end{array}$ \\
\hline Maintenance cost & $\begin{array}{c}491 \\
(1.1 \%)\end{array}$ & $\begin{array}{c}513 \\
(1.1 \%)\end{array}$ & $\begin{array}{c}736 \\
(1.1 \%)\end{array}$ & $\begin{array}{c}997 \\
(1.2 \%)\end{array}$ & $\begin{array}{c}1,741 \\
(1.5 \%) \\
\end{array}$ \\
\hline Insurance cost & $\begin{array}{c}154 \\
(0.3 \%)\end{array}$ & $\begin{array}{c}161 \\
(0.4 \%)\end{array}$ & $\begin{array}{c}231 \\
(0.3 \%)\end{array}$ & $\begin{array}{c}301 \\
(0.4 \%)\end{array}$ & $\begin{array}{c}545 \\
(0.5 \%)\end{array}$ \\
\hline Fuel cost & $\begin{array}{l}24,196 \\
(54.9 \%)\end{array}$ & $\begin{array}{l}25,815 \\
(56.7 \%)\end{array}$ & $\begin{array}{l}36,787 \\
(55.3 \%)\end{array}$ & $\begin{array}{l}43,787 \\
(53.9 \%)\end{array}$ & $\begin{array}{l}51,631 \\
(43.4 \%)\end{array}$ \\
\hline $\begin{array}{l}\text { Port dues, container } \\
\text { handling charge }\end{array}$ & $\begin{array}{c}8,822 \\
(20.0 \%)\end{array}$ & $\begin{array}{c}8,772 \\
(19.3 \%)\end{array}$ & $\begin{array}{l}13,932 \\
(20.9 \%)\end{array}$ & $\begin{array}{l}18,011 \\
(22.1 \%)\end{array}$ & $\begin{array}{c}33,931 \\
(28.5 \%)\end{array}$ \\
\hline Grand total & $\begin{array}{l}44,086 \\
(100 \%)\end{array}$ & $\begin{array}{l}45,522 \\
(100 \%)\end{array}$ & $\begin{array}{l}66,511 \\
(100 \%)\end{array}$ & $\begin{array}{l}81,011 \\
(100 \%)\end{array}$ & $\begin{array}{c}118,965 \\
(100 \%)\end{array}$ \\
\hline
\end{tabular}

